\title{
Physiological limits to zinc biofortification of edible crops
}

\author{
Philip J. White ${ }^{1 *}$ and Martin R. Broadley ${ }^{2}$ \\ ${ }^{1}$ The James Hutton Institute, Dundee, UK \\ 2 Plant and Crop Sciences Division, University of Nottingham, Loughborough, UK
}

\section{Edited by:}

Søren Husted, University of

Copenhagen, Denmark

\section{Reviewed by:}

Javier Abadía, Consejo Superior de Investigaciones Científicas, Spain

Ismail Cakmak, Sabanci University, Turkey

*Correspondence:

Philip J. White, The James Hutton Institute, Invergowrie, Dundee DD2 5DA, UK.

e-mail: philip.white@hutton.ac.uk
It has been estimated that one-third of the world's population lack sufficient $\mathrm{Zn}$ for adequate nutrition. This can be alleviated by increasing dietary Zn intakes through Zn biofortification of edible crops. Biofortification strategies include the application of $\mathrm{Zn}$-fertilizers and the development of crop genotypes that acquire more $\mathrm{Zn}$ from the soil and accumulate it in edible portions. Zinc concentrations in roots, leaves, and stems can be increased through the application of Zn-fertilizers. Root $\mathrm{Zn}$ concentrations of up to $500-5000 \mathrm{mg} \mathrm{kg}^{-1} \mathrm{dry}$ matter (DM), and leaf $Z n$ concentrations of up to $100-700 \mathrm{mg} \mathrm{kg}^{-1} \mathrm{DM}$, can be achieved without loss of yield when $\mathrm{Zn}$-fertilizers are applied to the soil. It is possible that greater $\mathrm{Zn}$ concentrations in non-woody shoot tissues can be achieved using foliar Zn-fertilizers. By contrast, $\mathrm{Zn}$ concentrations in fruits, seeds, and tubers are severely limited by low $\mathrm{Zn}$ mobility in the phloem and $\mathrm{Zn}$ concentrations higher than $30-100 \mathrm{mg} \mathrm{kg}^{-1} \mathrm{DM}$ are rarely observed. However, genetically modified plants with improved abilities to translocate $\mathrm{Zn}$ in the phloem might be used to biofortify these phloem-fed tissues. In addition, genetically modified plants with increased tolerance to high tissue $\mathrm{Zn}$ concentrations could be used to increase $\mathrm{Zn}$ concentrations in all edible produce and, thereby, increase dietary Zn intakes.

Keywords: Arabidopsis, bean, cassava, maize, potato, rice, wheat, zinc

\section{INTRODUCTION}

Zinc $(\mathrm{Zn})$ is an essential element for human nutrition (White and Broadley, 2005; Graham et al., 2007). Symptoms of Zn-deficiency include stunting, diarrhea, and pneumonia in children, with the latter two contributing significantly to infant mortality (Stein et al., 2005). The US recommended daily allowance (RDA, or adequate intake) of $\mathrm{Zn}$ is $8.0-13.0 \mathrm{mg}$ and the UK guidance daily reference nutrient intake (RNI) is $7.0-13.0 \mathrm{mg}$ for adults (Department of Health (UK), 1991; Institute of Medicine (USA), 2001). Unfortunately, the diets of many people across the world lack sufficient $\mathrm{Zn}$ for their adequate nutrition (White and Broadley, 2009; Bouis and Welch, 2010; Stein, 2010; Sayre et al., 2011). This has been attributed to sourcing produce from land with low mineral phytoavailability, eating crops with inherently low tissue mineral concentrations, or consuming processed foods. It has been estimated that almost one-third of the world's population consumes less $\mathrm{Zn}$ than the US RDA and that Zn-deficiency contributes 1.9\% of the overall burden of disease caused by major health risks worldwide (World Health Organization, 2002; Hotz and Brown, 2004). This has considerable socio-economic impacts (Stein, 2010).

Dietary $\mathrm{Zn}$ intakes can be increased through a variety of interventions (Stein, 2010). These include both agronomic and genetic biofortification of edible crops (Graham et al., 1999, 2001, 2007; White and Broadley, 2005, 2009; Cakmak, 2008; Khoshgoftarmanesh et al., 2009; Bouis and Welch, 2010; Martínez-Ballesta et al., 2010). Agronomic biofortification can be achieved by increasing soil Zn phytoavailability or by applying Zn-fertilizers. This requires appropriate infrastructures, but can be very successful in regions where mineral fertilizers are used to increase crop yields and $\mathrm{Zn}$ is added to these at the point of manufacture or distribution (Cakmak, 2004, 2009). Genetic biofortification is predicated on increasing $\mathrm{Zn}$ acquisition from the soil and its accumulation in edible portions. In most agricultural soils there is sufficient $\mathrm{Zn}$ to produce biofortified crops for many years, provided it becomes phytoavailable (Graham et al., 1999). Genetic biofortification strategies are, of course, ineffective if there is insufficient $\mathrm{Zn}$ present in the soil. Most economic analyses suggest that genetic strategies toward $\mathrm{Zn}$ biofortification are more practical, enduring, and cost effective than dietary diversification, supplementation, or food fortification programs for increasing dietary $\mathrm{Zn}$ intakes of vulnerable populations (Horton, 2006; Graham et al., 2007; Stein et al., 2007; Ma et al., 2008; Bouis and Welch, 2010; Meenakshi et al., 2010; Stein, 2010).

Several national and international projects are addressing $\mathrm{Zn}$ biofortification of edible crops (Graham et al., 2001, 2007; Cakmak, 2004; Pfeiffer and McClafferty, 2007; White and Broadley, 2009; Bouis and Welch, 2010; Stein, 2010; Sayre et al., 2011). The target $\mathrm{Zn}$ concentrations set by the HarvestPlus program are $28 \mu \mathrm{g} \mathrm{g}^{-1}$ dry matter (DM) in polished rice, $38 \mathrm{mg} \mathrm{kg}^{-1} \mathrm{DM}$ in wheat grain, $38 \mathrm{mg} \mathrm{kg}^{-1} \mathrm{DM}$ in maize, $66 \mathrm{mg} \mathrm{kg}^{-1} \mathrm{DM}$ in pearl millet, $56 \mathrm{mg} \mathrm{kg}^{-1} \mathrm{DM}$ in beans, $34 \mathrm{mg} \mathrm{kg}^{-1} \mathrm{DM}$ in cassava roots, and $70 \mathrm{mg} \mathrm{kg}^{-1} \mathrm{DM}$ in roots of sweet potatoes (Bouis and Welch, 2010). These target concentrations are considered to be conservative, and have been exceeded in breeding lines of rice, wheat, and maize (Bouis and Welch, 2010). This article asks whether higher target $\mathrm{Zn}$ concentrations can be achieved and, more broadly, what the physiological limits to $\mathrm{Zn}$ biofortification of crops might be. It considers (a) the physiological requirements and tolerance of $\mathrm{Zn}$ in crop plants, (b) the uptake and distribution of $\mathrm{Zn}$ between and within plant organs, (c) agronomic strategies to 
increase $\mathrm{Zn}$ concentrations of edible tissues, (d) genetic variation in $\mathrm{Zn}$ concentrations of edible portions within plant species, and (e) transgenic strategies to increase $\mathrm{Zn}$ concentrations of edible produce.

\section{PLANT PHYSIOLOGY}

PHYSIOLOGICAL REOUIREMENTS AND TOLERANCE OF ZINC IN PLANTS

Plants, like other living organisms, require $\mathrm{Zn}$ for the regulation of transcription and translation, the structural stability of proteins, the function of oxidoreductases and hydrolytic enzymes, and the control of enzyme activities (Broadley et al., 2007; Clemens, 2010; White, 2012b). However, excessive tissue $\mathrm{Zn}$ concentrations are toxic. Plant species differ in both their $\mathrm{Zn}$ requirements and their tolerance of high tissue $\mathrm{Zn}$ concentrations (Broadley et al., 2007; Fageria, 2009). Most crop plants require leaf $\mathrm{Zn}$ concentrations greater than $15-30 \mathrm{mg} \mathrm{kg}^{-1} \mathrm{DM}$ for maximal yield, and their growth is inhibited at leaf $\mathrm{Zn}$ concentrations greater than 100-700 $\mathrm{mg} \mathrm{kg}^{-1}$ DM (Fageria, 2009; White and Brown, 2010). By contrast plant species that hyperaccumulate $\mathrm{Zn}$, such as Noccaea caerulescens (formerly Thlaspi caerulescens) and Arabidopsis halleri, not only tolerate more $\mathrm{Zn}$ in their tissues than congeneric species that do not hyperaccumulate $\mathrm{Zn}$ but also require greater leaf $\mathrm{Zn}$ concentrations for optimal growth (Hammond et al., 2006; Broadley et al., 2007; White, 2012b). The trait of Zn hyperaccumulation is defined as a leaf $\mathrm{Zn}$ concentration exceeding $10,000 \mathrm{mg} \mathrm{kg}^{-1} \mathrm{DM}$ when plants are sampled from their natural habitat, although a figure of $3000 \mathrm{mg} \mathrm{kg}^{-1} \mathrm{DM}$ might be a more realistic threshold (Reeves and Baker, 2000; Broadley et al., 2007). Only 15-20 species hyperaccumulating $\mathrm{Zn}$ have been reported, mostly in the Brassicaceae (Broadley et al., 2007; Verbruggen et al., 2009; Krämer, 2010; White, 2012b). Zinc uptake, delivery to the xylem and tolerance in shoot tissues is maximized in plants that hyperaccumulate $\mathrm{Zn}$ (Broadley et al., 2007; White and Broadley, 2009; Krämer, 2010; Hassan and Aarts, 2011; Rascio and Navari-Izzo, 2011; White, 2012b). To achieve this, genes encoding enzymes synthesizing compounds enabling $\mathrm{Zn}$ uptake and xylem transport, and proteins catalyzing $\mathrm{Zn}$ uptake, vacuolar efflux and xylem loading are constitutively highly expressed in plants hyperaccumulating Zn (Hammond et al., 2006; Broadley et al., 2007; Hanikenne et al., 2008; Roosens et al., 2008; Verbruggen et al., 2009; Hassan and Aarts, 2011; Rascio and Navari-Izzo, 2011; Ó Lochlainn et al., 2011). Shoot $\mathrm{Zn}$ concentrations are often an order of magnitude greater than root $\mathrm{Zn}$ concentrations in plants that hyperaccumulate $\mathrm{Zn}$, although the exact ratio depends on soil Zn phytoavailability (Frey et al., 2000; Broadley et al., 2007). It is believed that the formation of $\mathrm{Zn}$-complexes and the translocation of $\mathrm{Zn}$ from the root to the shoot prevent the accumulation of toxic $\mathrm{Zn}$ concentrations in root tissues, thereby enabling plants that hyperaccumulate $\mathrm{Zn}$ to tolerate high $\mathrm{Zn}$ concentrations in the soil solution (Broadley et al., 2007; White, 2012b).

Plant species can differ greatly in their tissue $\mathrm{Zn}$ concentrations when grown under comparable conditions (Figure 1; Broadley et al., 2001, 2007). Shoot Zn concentrations are generally lower in the Ericales and commelinoid monocotyledons, and higher in the Brassicales, Caryophyllales, and non-commelinoid monocotyledons. Amongst the well-replicated plant families studied by Broadley et al. (2007), the lowest shoot $\mathrm{Zn}$ concentrations were

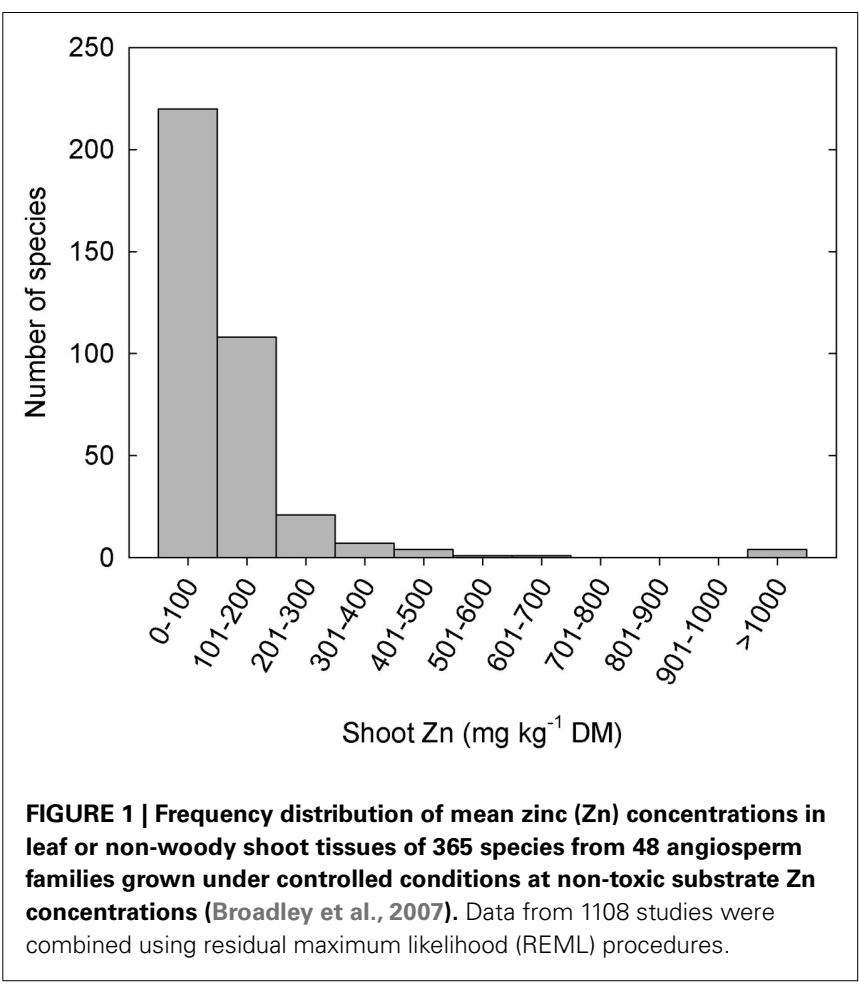

observed in the Linaceae, Poaceae, and Solanaceae, and the highest shoot $\mathrm{Zn}$ concentrations were observed in the Brassicaceae, Amaranthaceae, and Salicaceae. These phylogenetic effects on shoot $\mathrm{Zn}$ concentration are also observed in surveys of plants growing in their natural habitats (Watanabe et al., 2007). Similarly, seeds of cereals generally have lower $\mathrm{Zn}$ concentrations than seeds of legumes (Figure 2). As a consequence, the occurrence of $\mathrm{Zn}$ deficiency disorders has increased in populations changing from traditional diets dominated by pulses, vegetables, and fruits to diets dominated by cereals (Graham et al., 2001).

\section{THE UPTAKE AND DISTRIBUTION OF ZINC BETWEEN AND WITHIN PLANT ORGANS}

Zinc is unevenly distributed within the plant. When plants are supplied $\mathrm{Zn}$ through the rhizosphere, tissue $\mathrm{Zn}$ concentrations generally decrease in the order root $\approx$ shoot $>$ fruit, seed, tuber (Broadley et al., 2012). Consequently Zn concentrations are often greater in root crops and leafy vegetables than in grain, seed, fruit, or tuber crops (Figure 2; White and Broadley, 2005, 2009; Pfeiffer and McClafferty, 2007). Within each organ, $\mathrm{Zn}$ is preferentially accumulated by specific cell types. For example $\mathrm{Zn}$ is often localized in distinct regions within the root, such as the elongation zone, and is concentrated in endodermal cells of dicotyledonous species and in the pericycle of monocotyledonous species (Van Steveninck et al., 1994). The distribution of $\mathrm{Zn}$ within shoots and leaves varies between plant species. For example, in N. caerulescens, leaf epidermal cells, with the exception of guard cells, have greater $\mathrm{Zn}$ concentrations than leaf mesophyll cells and leaf $\mathrm{Zn}$ concentrations are higher in older leaves (Vázquez et al., 1994; Küpper et al., 1999, 2004; Frey et al., 2000; Ma et al., 2005; Monsant et al., 2010), whereas in A. halleri, and in Arabidopsis murale, $\mathrm{Zn}$ is more 


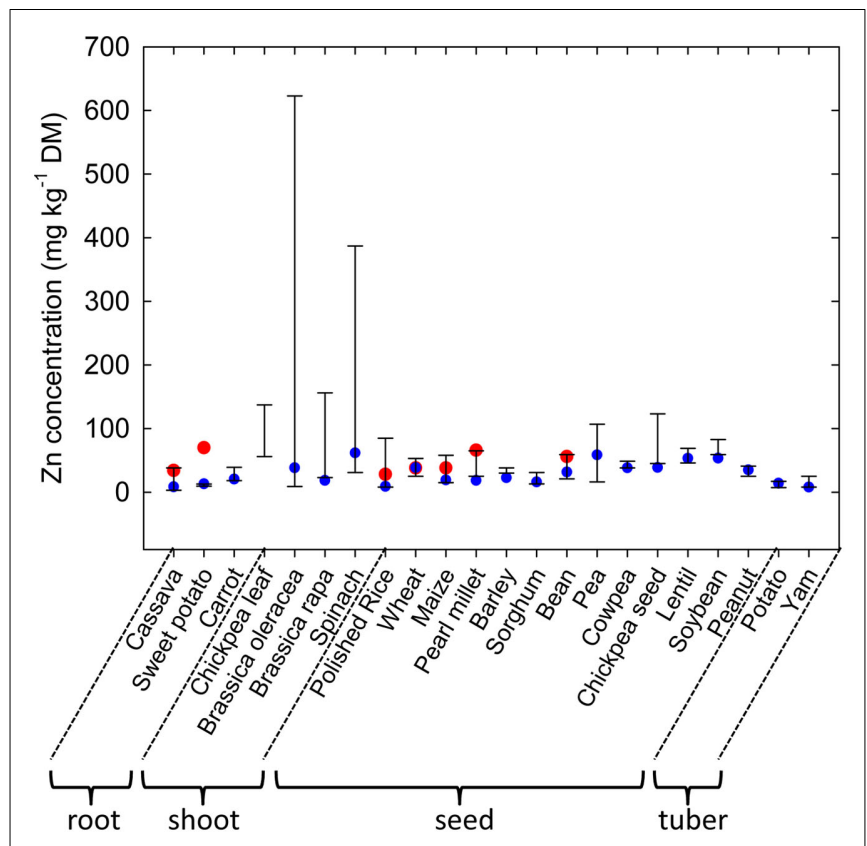

FIGURE 2 | Variation in zinc $(\mathrm{Zn})$ concentrations in roots, shoots, seeds and tubers of edible crops. Bars represent maximum and minimum values obtained for large collections of cassava (Chávez et al., 2005), sweet potato (Pfeiffer and McClafferty, 2007), carrot (Nicolle et al., 2004), chickpea (leaves; Ibrikci et al., 2003), Brassica oleracea (Broadley et al., 2010), Brassica rapa (Wu et al., 2007), spinach (Grusak and Cakmak, 2005), rice (Nang et al., 1998), wheat (Graham et al., 1999), maize (Bänziger and Long, 2000), pearl millet Nelu et al., 2007), barley (P. J. White and I. J. Bingham cited in White and Broadley, 2009), sorghum (Reddy et al., 2005), bean (Islam et al., 2002), pea (Grusak and Cakmak, 2005), cowpea (Pfeiffer and McClafferty, 2007), chickpea (seed, M. A. Grusak cited in White and Broadley, 2009), lentil (Pfeiffer and McClafferty, 2007), soybean (Raboy et al., 1984), peanut (Branch and Gaines, 1983), potatoes White et al., 2009), and yam (Agbor-Egbe and Trèche, 1995) genotypes. Blue circles indicate $\mathrm{Zn}$ concentrations in the U.S. Department of Agriculture, Agricultural Research Service (2011). Red circles indicate target Zn concentrations proposed by the HarvestPlus program (Bouis and Welch, 2010).

uniformly distributed across the leaf, although mesophyll cells have higher $\mathrm{Zn}$ concentrations than trichomes, which have greater Zn concentrations than other epidermal cells (Küpper et al., 2000; Zhao et al., 2000; Tappero et al., 2007). In seeds of cereals, $\mathrm{Zn}$ is preferentially accumulated in the husk, aleurone layers or embryo (Lin et al., 2005; Ozturk et al., 2006; Liu et al., 2007; Hansen et al., 2009; Persson et al., 2009; Cakmak et al., 2010a,b; Lombi et al., 2011; Stomph et al., 2011). In potato tubers about $17 \%$ of total tuber $\mathrm{Zn}$ is present in the skin (Subramanian et al., 2011). These distribution patterns reflect both local and long-distance transport of $\mathrm{Zn}$ within the plant (Broadley et al., 2007; Stomph et al., 2011; Subramanian et al., 2011). The distribution of $\mathrm{Zn}$ within cereal seeds and tubers will reduce the potential dietary $Z n$ intakes from these crops when, for example, polished grains or peeled tubers are consumed.

Plant tissues accumulate $\mathrm{Zn}$ in both soluble and insoluble forms (Broadley et al., 2007). In crop plants, much of the soluble $\mathrm{Zn}$ is complexed with organic compounds. These compounds include carboxylic acids, such as citrate, malate, and oxalate, amino acids, such as histidine and asparagine, glutathione, phytochelatins, nicotianamine (NA), and proteins. In addition, $\mathrm{Zn}$ is found as phosphate salts, such as $\mathrm{Zn}_{3}\left(\mathrm{PO}_{4}\right)_{2}$, and organic $\mathrm{Zn}$-phytates. In the apoplast, $\mathrm{Zn}^{2+}$ binds to negatively charged cell-wall components, organic acids and phytosiderophores if these are present, and can be precipitated as phosphate or phytate salts when its concentration in the apoplast becomes excessive (Van Steveninck et al., 1994; Broadley et al., 2007; Straczek et al., 2008; Terzano et al., 2008; Kopittke et al., 2011). In the cytosol, $\mathrm{Zn}$ can be complexed by proteins, glutathione, phytochelatins and $\mathrm{NA}$, and $\mathrm{Zn}^{2+}$ concentrations are vanishingly low (Broadley et al., 2007; Roosens et al., 2008; Clemens, 2010). The vacuoles of root and leaf cells contain $\mathrm{Zn}$ largely as $\mathrm{Zn}^{2+}$ and $\mathrm{Zn}$-organic acid complexes (Broadley et al., 2007; Straczek et al., 2008; Sarret et al., 2009). Within the xylem, $\mathrm{Zn}$ is also present predominantly as $\mathrm{Zn}^{2+}$ and as complexes with carboxylic acids, such as citrate and malate (Welch, 1995; Broadley et al., 2007; Terzano et al., 2008). By contrast, phloem sap contains little $\mathrm{Zn}^{2+}$, and $\mathrm{Zn}$ is thought to be transported complexed with NA or small proteins (Welch, 1995; Curie et al., 2009; Waters and Sankaran, 2011).

The forms of $\mathrm{Zn}$ present in tissues of plants that hyperaccumulate $\mathrm{Zn}$ depends on the plant species, the tissue studied, and the concentration of $\mathrm{Zn}$ in that tissue (Küpper et al., 2004; Sarret et al., 2009; Monsant et al., 2011). More than $30 \%$ of the $\mathrm{Zn}$ in roots of N. caerulescens is generally associated with cell walls, and much of the remainder is complexed with histidine (Salt et al., 1999; Monsant et al., 2010, 2011). The presence of Zn-phytate is also observed occasionally (Monsant et al., 2011). About $80 \%$ of the $\mathrm{Zn}$ in the xylem sap of this plant species is $\mathrm{Zn}^{2+}$, with the remainder complexed with carboxylic acids (Salt et al., 1999; Monsant et al., 2011). In shoots of Zn-hyperaccumulator plants, such as $N$. caerulescens and A. halleri, $20-50 \%$ of the $\mathrm{Zn}$ is present as $\mathrm{Zn}^{2+}, 40-99 \%$ is associated with vacuolar carboxylic acids, such as citrate, malate, and oxalate, up to $45 \%$ can be associated with histidine, and the remainder is largely bound to phosphate-groups and cell-wall components (Salt et al., 1999; Küpper et al., 2004; Sarret et al., 2009; Monsant et al., 2011). No major contributions of phytochelatins, metallothioneins, or other cysteine-rich peptides are observed (Küpper et al., 2004; Sarret et al., 2009).

In general, $\mathrm{Zn}$ enters plants from the soil solution and is transported either symplastically, following uptake by root cells, or apoplastically, in regions of the root lacking a Casparian Band, to the stele where it enters the xylem (White et al., 2002b; Broadley et al., 2007). Zinc is taken up by root cells as $\mathrm{Zn}^{2+}$ and, in some plant species, also as Zn-phytosiderophore complexes (Broadley et al., 2007; Palmer and Guerinot, 2009; Puig and Peñarrubia, 2009; Verbruggen et al., 2009; White and Broadley, 2009; Clemens, 2010; Krämer, 2010; White, 2012b). Although some plasma membrane $\mathrm{Ca}^{2+}$ channels are permeable to $\mathrm{Zn}^{2+}$ (Demidchik et al., 2002; White et al., 2002a), it is thought that most $\mathrm{Zn}^{2+}$ influx to the cytoplasm of root cells is mediated by ZRT-, IRT-like proteins (ZIPs), in Arabidopsis thaliana principally AtZIP4 and AtIRT1, and that yellow stripe like proteins (YSLs) catalyze the uptake of $\mathrm{Zn}$ phytosiderophore complexes in cereals and grasses (Broadley et al., 2007; Roosens et al., 2008; Curie et al., 2009; Palmer and Guerinot, 2009; Verbruggen et al., 2009; White and Broadley, 2009; Waters 
and Sankaran, 2011; White, 2012b). In the cytosol of root cells, $\mathrm{Zn}^{2+}$ is complexed by numerous proteins, including many that modulate enzymic activities or gene transcription, by glutathione, by phytochelatins, and by NA, and the cytosolic $\mathrm{Zn}^{2+}$ concentration is likely to be extremely low (Broadley et al., 2007; Roosens et al., 2008; Clemens, 2010).

Members of the cation diffusion facilitator (CDF) family, such as orthologs of the A. thaliana metal tolerance proteins AtMTP1 and AtMTP3, and the $\mathrm{Mg}^{2+} / \mathrm{H}^{+}$antiporter AtMHX, transport $\mathrm{Zn}^{2+}$ into the vacuole, whilst orthologs of the A. thaliana $\mathrm{Zn}$ induced facilitator 1 (AtZIF1) protein transport $\mathrm{Zn}^{2+}$-complexes into the vacuole (Roosens et al., 2008; Palmer and Guerinot, 2009; Puig and Peñarrubia, 2009; White and Broadley, 2009; Clemens, 2010; Hassan and Aarts, 2011). It is thought that $\mathrm{Zn}$ is sequestered in the vacuole as an organic acid complex (Broadley et al., 2007). Zinc is released from the root vacuole through NRAMPs, including orthologs of the AtNRAMP3 and AtNRAMP4 transporters of A. thaliana (Roosens et al., 2008; Verbruggen et al., 2009). Members of the heavy metal $\mathrm{P}_{1 \mathrm{~B}}$-ATPase family, such as AtHMA2 and AtHMA4 in A. thaliana, load $\mathrm{Zn}^{2+}$ into the xylem (Roosens et al., 2008; Palmer and Guerinot, 2009; Puig and Peñarrubia, 2009; Verbruggen et al., 2009; White and Broadley, 2009; Waters and Sankaran, 2011; White, 2012b). Within the xylem, $\mathrm{Zn}$ is transported either as $\mathrm{Zn}^{2+}$ or as a complex with organic acids or NA, and it is thought that YSL proteins load Zn-NA complexes into the xylem and orthologs of AtFRD3 load citrate into the xylem to promote Zn transport (Broadley et al., 2007; Roosens et al., 2008; Waters and Grusak, 2008; Curie et al., 2009; Waters and Sankaran, 2011).

Within the shoot, the uptake of $\mathrm{Zn}^{2+}$ and $\mathrm{Zn}$-complexes by specific cell types are facilitated by members of the ZIP and YSL families, respectively (White and Broadley, 2009; Waters and Sankaran, 2011). Members of these protein families are also thought to load Zn into the phloem (Curie et al., 2009; White and Broadley, 2009), where it is transported as a complex with NA or small proteins (Curie et al., 2009; Puig and Peñarrubia, 2009; White and Broadley, 2009; Waters and Sankaran, 2011). In A. thaliana, AtYSL1, AtYSL3, and AtOPT3 have been implicated in delivering $\mathrm{Zn}$ from vascular tissues to developing seeds (Waters and Grusak, 2008; Puig and Peñarrubia, 2009; Waters and Sankaran, 2011). The mobility of $\mathrm{Zn}$ in the phloem will determine $\mathrm{Zn}$ accumulation by phloem-fed tissues, such as fruits, seeds, and tubers. Although $\mathrm{Zn}$ is generally considered to have a low mobility in the phloem (Fageria, 2009; White, 2012a), the translocation of $\mathrm{Zn}$ in the phloem of several plant species following the application of foliar $\mathrm{Zn}$-fertilizers has been found to be nutritionally significant for their growth and development especially when cultivated in substrates with low $\mathrm{Zn}$ phytoavailability (Haslett et al., 2001; Brown, 2009; Waters and Sankaran, 2011).

The activity of transport proteins catalyzing $\mathrm{Zn}$ uptake, and the expression of the genes encoding proteins responsible for the mobilization of transition-metal elements from soil, their uptake by plant roots, and their distribution within the plant are regulated in response to plant $Z n$ status to ensure appropriate tissue Zn concentrations. Thus, ZIPs, YSLs, HMAs, MTPs, ZIF1, FRD3, and enzymes involved in the synthesis of phytosiderophores and NA are upregulated during Zn-deficiency and downregulated when plant tissues have sufficient $\mathrm{Zn}$ for their physiological requirements (Broadley et al., 2007; White and Broadley, 2009; Waters and Sankaran, 2011). Recently, two members of the basic region/leucine zipper motif (bZIP) transcription factor gene family, bZIP19 and bZIP23, were shown to coordinate the adaptation of A. thaliana to low Zn phytoavailability (Assunção et al., 2010). This general homeostatic regulation of tissue $\mathrm{Zn}$ concentrations through $\mathrm{Zn}$ acquisition and distribution within the plant could limit $\mathrm{Zn}$ accumulation by edible tissues.

\section{AGRONOMIC STRATEGIES TO INCREASE ZINC CONCENTRATIONS OF EDIBLE CROPS}

Although the total $\mathrm{Zn}$ concentrations in many soils are sufficient to support mineral-dense crops (Graham et al., 1999) Zn uptake by plants is often limited by its phytoavailability and acquisition by roots (Broadley et al., 2007; White and Broadley, 2009). Agronomic strategies seek to improve $\mathrm{Zn}$ phytoavailability in the soil, for example by remedying soil alkalinity, adopting appropriate crop rotations or introducing beneficial soil microorganisms (Rengel et al., 1999; He and Nara, 2007; Fageria, 2009; White and Broadley, 2009), or to deliver phytoavailable $\mathrm{Zn}$ through the application of Zn-fertilizers to soil or foliage (Cakmak, 2004; Graham et al., 2007; Fageria, 2009; White and Broadley, 2009; Bouis and Welch, 2010). Common inorganic Zn-fertilizers include $\mathrm{ZnSO}_{4}, \mathrm{ZnO}$, and synthetic Zn-chelates (Fageria, 2009; White and Broadley, 2009). When $\mathrm{Zn}$-fertilizers are applied to foliage, it is particularly important that the $\mathrm{Zn}$ compounds used are readily soluble, enter the leaf apoplast, and can be taken up by plant cells (Haslett et al., 2001; Cakmak, 2008; Brown, 2009). This avoids the accumulation of $\mathrm{Zn}$ salts on the surface of leaves or in the leaf apoplast, which can interfere with photosynthesis and cell function, and promotes the translocation of $\mathrm{Zn}$ from leaves to phloem-fed tissues.

Zinc concentrations in roots, leaves, and stems can be increased readily by applying $\mathrm{Zn}$-fertilizers to the soil in plants growing on most, but not all, soils and by foliar application of $\mathrm{Zn}$-fertilizers (Figure 3; Rengel et al., 1999; Cakmak, 2008; Fageria, 2009; Sagardoy et al., 2009; White and Broadley, 2009; Bouis and Welch, 2010). Thus, $\mathrm{Zn}$ concentrations in these tissues will be limited solely by $\mathrm{Zn}$ toxicity. When $\mathrm{Zn}$-fertilizers are added to the soil, root tissues often exhibit higher $\mathrm{Zn}$ concentrations than shoot tissues, and it is likely that plant $\mathrm{Zn}$ accumulation and yield is limited by $\mathrm{Zn}$ toxicity to root cells under these conditions. Critical leaf $\mathrm{Zn}$ concentrations for most crop plants lie between 100 and $700 \mathrm{mg} \mathrm{kg}^{-1} \mathrm{DM}$ when $\mathrm{Zn}$-fertilizers are applied to the soil (MacNicol and Beckett, 1985; Fageria, 2009). It is possible that, when $\mathrm{Zn}$-fertilizers are applied foliarly, higher leaf $\mathrm{Zn}$ concentrations might be achieved without loss of yield (Cakmak et al., 1999; White et al., submitted).

Soil or foliar applications of $\mathrm{Zn}$-fertilizers can also increase $\mathrm{Zn}$ concentrations in phloem-fed tissues, such as fruits, seeds, and tubers (Rengel et al., 1999; Cakmak, 2004, 2008; Fang et al., 2008; White et al., 2009; Cakmak et al., 2010a,b). However, increasing $\mathrm{Zn}$ concentrations in these tissues requires adequate $\mathrm{Zn}$ mobility in the phloem and, unless $\mathrm{Zn}$-fertilizers are applied directly or they have functional xylem continuity, the mobility of $\mathrm{Zn}$ in the phloem will limit their $\mathrm{Zn}$ accumulation (Rengel et al., 

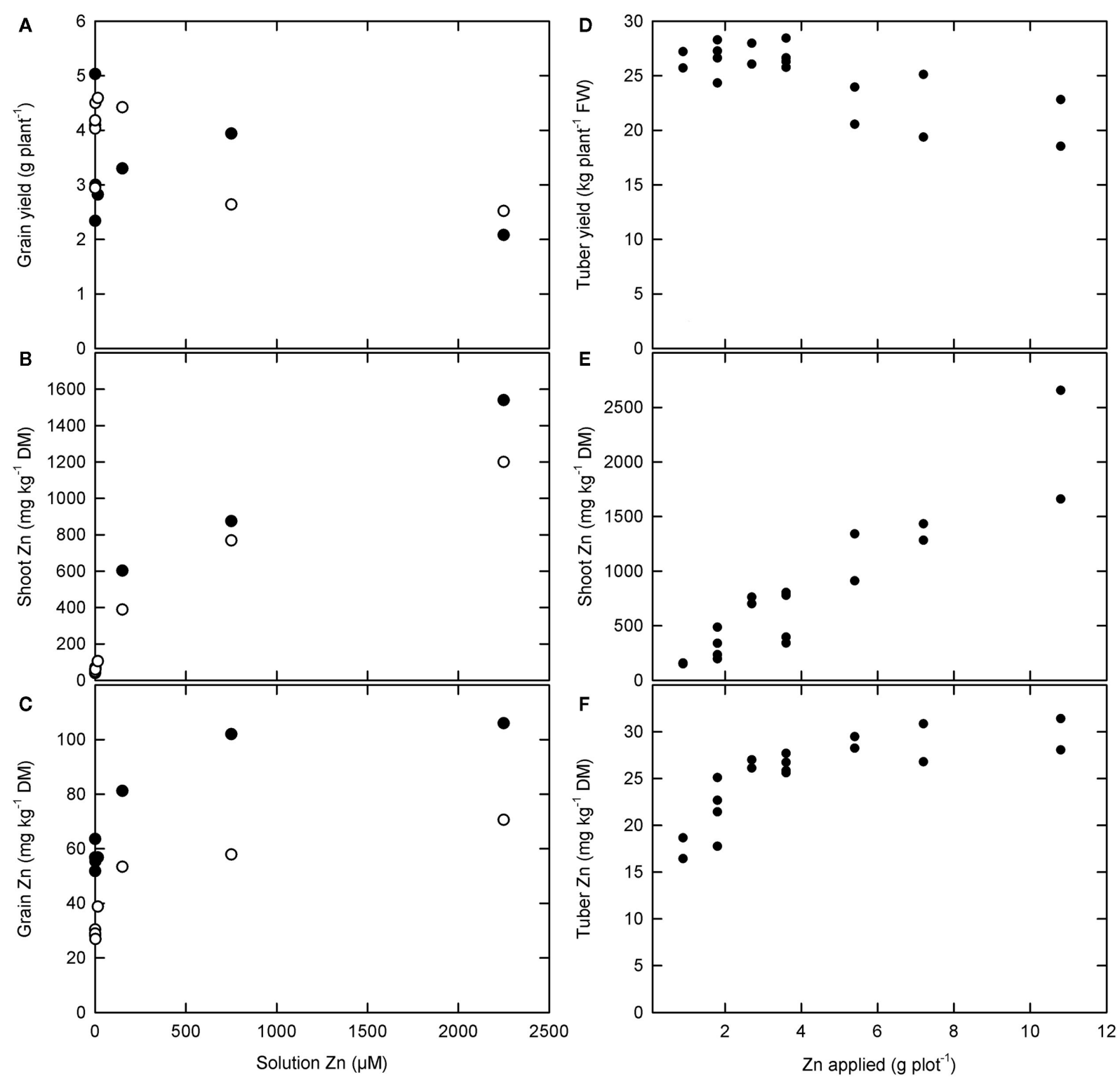

FIGURE 3 | (A-C) The effect of solution zinc ( $\mathrm{Zn}$ ) concentration on (A) grain yield and $\mathrm{Zn}$ concentrations in (B) shoots and (C) grain of two rice varieties, Handao297 (filled circles) and K150 (open

circles), grown in quartz sand irrigated with a complete nutrient

solution (Jiang et al., 2008). (D-F) The effect of foliar Zn fertilizer applications on (D) tuber yield and (E) shoot and (F) tuber Zn

concentrations in "Maris Piper" potatoes grown in the field (White et al., submitted).

1999; White and Broadley, 2005, 2009; Broadley et al., 2007; Stomph et al., 2009; Cakmak et al., 2010a,b; White et al., submitted). The relationship between seed $\mathrm{Zn}$ concentration and Zn phytoavailability often follows a saturation curve. For example, when rice is grown in quartz sand irrigated with a complete nutrient solution, $\mathrm{Zn}$ concentrations in brown rice reach a maximum of about $50-110 \mathrm{mg} \mathrm{Zn} \mathrm{kg}{ }^{-1} \mathrm{DM}$ depending upon variety (Figure 3; Jiang et al., 2008). Similarly, the relationship between tuber $\mathrm{Zn}$ concentration and foliar Zn application in "Maris Piper" potatoes grown in the field followed a saturation curve, reaching a maximum of about $30 \mathrm{mg} \mathrm{Zn} \mathrm{kg}^{-1} \mathrm{DM}$ (Figure 3; White et al., submitted). In the phloem, $\mathrm{Zn}$ is thought to be transported either as Zn-NA or complexed with small proteins (White and Broadley, 2009). In cereals, grain $\mathrm{Zn}$ concentration is correlated with grain protein concentration (e.g., Zhao et al., 2009; Cakmak et al., 2010a,b; Gomez-Becerra et al., 2010), and the limit to grain $\mathrm{Zn}$ concentration can be increased by higher $\mathrm{N}$-fertilizer applications (Hao et al., 2007; Kutman et al., 2010, 2011a,b; Shi et al., 2010). Similarly, there is a significant relationship between tuber $\mathrm{Zn}$ concentration and tuber $\mathrm{N}$ concentration among potato genotypes (White et al., submitted) and tuber $\mathrm{Zn}$ concentrations can be increased by N-fertilization (Hlusek et al., 1997). Nevertheless, $\mathrm{Zn}$ concentrations in phloem-fed tissues rarely exceed 30-100 $\mathrm{mg} \mathrm{kg}^{-1} \mathrm{DM}$. 


\section{GENETIC VARIATION IN ZINC CONCENTRATIONS OF EDIBLE CROPS}

Genetic strategies to increase $\mathrm{Zn}$ concentrations in edible portions seek to exploit genetic variation in the acquisition of $\mathrm{Zn}$ from the soil, $\mathrm{Zn}$ accumulation in edible portions and tolerance to high tissue Zn concentrations (Pfeiffer and McClafferty, 2007; White and Broadley, 2009). There is considerable genetic variation in $\mathrm{Zn}$ concentration in most edible crops (Figure 2). Edible roots often have low $\mathrm{Zn}$ concentrations, but researchers have reported $>14$-fold variation in root $\mathrm{Zn}$ concentrations among 600 cassava genotypes (Chávez et al., 2005) and 2.2-fold variation among 20 carrot genotypes (Nicolle et al., 2004). Zinc concentrations in edible greens are often relatively high and trials have indicated 2.5-fold variation in leaf Zn-concentration among 19 chickpea genotypes (Ibrikci et al., 2003), 6.7-fold variation in leaf Zn-concentration among 111 Brassica rapa genotypes (Wu et al., 2007), 12.3-fold variation in leaf $\mathrm{Zn}$-concentration among 327 spinach genotypes (Grusak and Cakmak, 2005), and over 26fold variation among 339 Brassica oleracea genotypes (Broadley et al., 2010). Absolute $\mathrm{Zn}$ concentrations and genetic variation in $\mathrm{Zn}$ concentrations are often lower in seeds than in leaves. Nevertheless, between 2.2- and 11.6-fold variation in seed $\mathrm{Zn}$ concentrations have been observed in large core collections of cereal germplasm (e.g., Yang et al., 1998; Graham et al., 1999; Bänziger and Long, 2000; Gregorio et al., 2000; Reddy et al., 2005) and between 1.8- and 6.6-fold variation in seed $\mathrm{Zn}$ concentrations in large core collections of legume germplasm (Raboy et al., 1984; Islam et al., 2002; Grusak and Cakmak, 2005; Pfeiffer and McClafferty, 2007; White and Broadley, 2009). Fruits generally have low $\mathrm{Zn}$ concentrations, and studies report about twofold variation among three to six cultivars in strawberries (Hakala et al., 2003), apples (Iwane, 1991), and plantains (Davey et al., 2007). Similarly, although tuber Zn concentrations are relatively low, 2.4-fold and 3.1-fold variation has been reported among 26 potato and 23 yam genotypes, respectively (Agbor-Egbe and Trèche, 1995; White et al., 2009). These data indicate that breeding for increased $\mathrm{Zn}$ concentrations is, in principle, feasible for most edible crops. Indeed, genetic loci (QTL) affecting Zn concentrations in cereal grain (Distelfeld et al., 2007; Stangoulis et al., 2007; Genc et al., 2009; Lonergan et al., 2009; Peleg et al., 2009), bean seeds (Guzmán-Maldonado et al., 2003; Cichy et al., 2005, 2009; Gelin et al., 2007; Blair et al., 2009, 2010, 2011), brassica leaves (Wu et al., 2008; Broadley et al., 2010), and potato tubers (N. K. Subramanian et al., unpublished data) have been identified.

\section{GENETIC MODIFICATION STRATEGIES FOR ZINC BIOFORTIFICATION OF EDIBLE CROPS}

It has been speculated that the constitutive expression of a suite of Zn-deficiency inducible responses through the overexpression of bZIP19 and bZIP23 transcription factors could be used to increase $\mathrm{Zn}$ accumulation in edible portions of crop plants (Assunção et al., 2010). Specific targets for the manipulation of root $\mathrm{Zn}$ concentrations include transport proteins in the plasma membrane and tonoplast of root cells that facilitate the uptake and sequestration of $\mathrm{Zn}$ in the vacuole, together with enzymes involved in the synthesis of compounds that bind $\mathrm{Zn}^{2+}$ in the rhizosphere, cytoplasm, and vacuole. Targets for the manipulation of shoot $\mathrm{Zn}$ concentrations include (a) transport proteins in the plasma membrane of root cells that facilitate $\mathrm{Zn}$ uptake and delivery to the xylem, or root structural modifications that facilitate apoplastic movement to the xylem, (b) enzymes involved in the synthesis of compounds that facilitate $\mathrm{Zn}$ movement through the root symplast or apoplast and in the xylem, (c) transport proteins in the plasma membrane and tonoplast of shoot cells that facilitate $\mathrm{Zn}$ uptake and vacuolar Zn sequestration, and (d) enzymes involved in the synthesis of compounds that detoxify $\mathrm{Zn}^{2+}$ within and outside shoot cells. Targets for the manipulation of $\mathrm{Zn}$ concentrations in phloem-fed tissues will additionally include transport proteins in the plasma membrane of shoot cells that facilitate the loading of $\mathrm{Zn}$ into the phloem and compounds that facilitate $\mathrm{Zn}$ movement in the phloem.

Most published studies describing GM strategies that increase Zn concentrations in plant tissues have been performed on "model" plants such as A. thaliana and, even when studies have been performed on crop species, data on commercial yields are rarely presented. Yield per plant can have a substantial effect on the tissue concentrations of mineral elements through dilution effects caused by plant growth (Jarrell and Beverly, 1981; Davis, 2011). Higher-yielding genotypes often have lower $\mathrm{Zn}$ concentrations in their edible tissues than lower-yielding genotypes (Monasterio and Graham, 2000; Garvin et al., 2006; Murphy et al., 2008; White et al., 2009; Zhao et al., 2009). Thus, it is important to consider whether any increase in tissue $\mathrm{Zn}$ concentration is simply a consequence of slower growth or reduced yields.

Overexpressing genes encoding $\mathrm{Zn}$-transporters catalyzing $\mathrm{Zn}^{2+}$ influx to root cells often increases root $\mathrm{Zn}$ concentrations but reduces leaf $Z n$ concentrations. This has been observed when overexpressing OsZIP4 or OsZIP5 in rice (Ishimaru et al., 2007; Lee et al., 2010) and when overexpressing AtZIP1 in cassava (Sayre et al., 2011). Overexpressing a root plasma membrane $\mathrm{Zn}$-transporter, AtZIP1, in barley had no effect on leaf $\mathrm{Zn}$ concentration, but reduced seed weight and increased seed $\mathrm{Zn}$ concentrations from 31 to $61-85 \mathrm{mg} \mathrm{kg}^{-1} \mathrm{DM}$ (Ramesh et al., 2004). Overexpression of the ZIPs TcZNT5 and TcZNT6 in A. thaliana had no consistent effects on root or shoot $\mathrm{Zn}$ concentrations (Wu et al., 2009). Overexpressing genes encoding proteins that transport $\mathrm{Zn}^{2+}$ into the vacuole, such as AtMTP1 (AtZAT1), AtMTP3, or TgMTP1, increases $\mathrm{Zn}$ uptake and root $\mathrm{Zn}$ concentrations, but rarely shoot $\mathrm{Zn}$ concentrations, when expressed in roots, and increases $\mathrm{Zn}$ uptake and leaf $\mathrm{Zn}$ concentrations, but rarely seed $\mathrm{Zn}$ concentrations, through systemic induction of Zn-deficiency responses when expressed in the shoot (van der Zaal et al., 1999; Arrivault et al., 2006; Gustin et al., 2009). The expression of AtMTP1 (AtZAT1) increased Zn concentrations in roots of cassava about fourfold to $40 \mathrm{mg} \mathrm{kg}^{-1} \mathrm{DM}$ (Sayre et al., 2011). The ferric reductase defective 3/manganese accumulator 1 $(f r d 3=\operatorname{man} 1)$ null mutants of $A$. thaliana, which constitutively express genes allowing increased rhizosphere $\mathrm{Fe}(\mathrm{III})$ reductase activity (AtFRO2), Zn uptake (AtIRT1), and tissue NA concentrations, have greater shoot $\mathrm{Zn}$ concentrations, but similar seed $\mathrm{Zn}$ concentrations, to wild-type plants (Rogers and Guerinot, 2002). Similarly, a mutant of $A$. thaliana (opt3.2) with reduced expression of AtOPT3 that shows constitutive expression of AtFRO2 
and AtIRT1 has higher $\mathrm{Zn}$ concentrations in leaves, stems, and seed than wild-type plants (Stacey et al., 2008). Overexpressing enzymes involved in the synthesis of phytosiderophores, either HvIDS3 (encoding a dioxygenase, referred to as Iron-Deficiency Specific clone 3) alone or both HvNAS1 (encoding nicotianamine synthase) and $H v N A A T$ (encoding nicotianamine aminotransferase) increased concentrations of $\mathrm{Zn}$ in seeds of paddy-grown rice from $11.2 \mathrm{mg} \mathrm{kg}^{-1} \mathrm{DM}$ to 13.4 and $15.3 \mathrm{mg} \mathrm{kg}^{-1} \mathrm{DM}$, respectively (Suzuki et al., 2008). Leaf $Z n$ concentrations can be increased in A. thaliana by reducing the expression of AtHMA2, which is thought to catalyze $\mathrm{Zn}^{2+}$ efflux across the membranes of root cells (Eren and Argüello, 2004) or by overexpressing the gene encoding AtHMA4, which is thought to load $\mathrm{Zn}$ into the xylem (Verret et al., 2004).

The overexpression of genes encoding nicotianamine synthase (NAS) often leads to increased $\mathrm{Zn}$ concentrations in leaves and grain. The overexpression of HvNAS1 in tobacco increased leaf $\mathrm{Zn}$ concentrations from 16 to $39 \mathrm{mg} \mathrm{kg}^{-1} \mathrm{DM}$ and seed $\mathrm{Zn}$ concentrations from 20 to $35 \mathrm{mg} \mathrm{kg}^{-1}$ DM (Takahashi et al., 2003). The overexpression of OsNAS3 in rice also increased leaf and seed Zn concentrations (Lee et al., 2009; Johnson et al., 2011). Seed $\mathrm{Zn}$ concentrations of glasshouse-grown plants were increased from $\sim 40$ to $79 \mathrm{mg} \mathrm{kg}^{-1} \mathrm{DM}$ (Johnson et al., 2011) and those of paddy-grown plants were increased from 16 to $35 \mathrm{mg} \mathrm{kg}^{-1} \mathrm{DM}$ (Lee et al., 2009). Constitutive overexpression of OsNAS2 in rice resulted in an increase in seed $\mathrm{Zn}$ concentrations from $\sim 23$ to $\sim 60 \mathrm{mg} \mathrm{kg}^{-1} \mathrm{DM}$ (Lee et al., 2011) and from $\sim 40$ to $95 \mathrm{mg} \mathrm{kg}^{-1}$ DM (Johnson et al., 2011) in two independent studies. Constitutive overexpression of OsNAS1 in rice resulted in an increase in seed $\mathrm{Zn}$ concentrations from $\sim 40$ to $59 \mathrm{mg} \mathrm{kg}^{-1} \mathrm{DM}$ (Johnson et al., 2011). The maximum $\mathrm{Zn}$ concentrations in polished grain of transgenic rice expressing Pvferritin in the endosperm and AtNAS1 throughout the plant was $34 \mathrm{mg} \mathrm{kg}^{-1} \mathrm{DM}$, about $50 \%$ greater than in wild-type plants (Wirth et al., 2009). Earlier studies of plants expressing only Gmferritin found $\sim 56 \mathrm{mg} \mathrm{Zn} \mathrm{kg}^{-1} \mathrm{DM}$ in brown rice (Vasconcelos et al., 2003). The overexpression of genes increasing the production of glutathione, phytochelatins, and total thiols resulted in increased leaf $\mathrm{Zn}$ concentrations in Indian mustard (Brassica juncea) grown on soils with high $\mathrm{Zn}$ phytoavailability (Bennett et al., 2003). Seed Zn concentrations can be increased in wheat by increasing the expression of a NAC transcription factor (NAM-B1) that accelerate senescence and increase remobilization of mineral elements from leaves to developing grain (Uauy et al., 2006).

\section{CONCLUSION}

Zinc concentrations in roots, leaves, and stems can be increased greatly by applying $\mathrm{Zn}$-fertilizers (Figure 3 ). The accumulation of $\mathrm{Zn}$ in these tissues appears to be limited by $\mathrm{Zn}$ toxicity. In some crops, such as cereals and beans, root $\mathrm{Zn}$ concentrations of between 500 and $5000 \mathrm{mg} \mathrm{kg}^{-1} \mathrm{DM}$ have been reported without loss of yield (Reichman, 2002). Leaf $\mathrm{Zn}$ concentrations $\geq 100 \mathrm{mg} \mathrm{kg}^{-1}$ $\mathrm{DM}$, and perhaps up to $700 \mathrm{mg} \mathrm{kg}^{-1} \mathrm{DM}$, can be achieved without loss of yield in $\mathrm{Zn}$-tolerant crops when $\mathrm{Zn}$-fertilizers are applied to the soil (Fageria, 2009). It is possible that greater Zn concentrations in non-woody shoot tissues might be achieved using foliar
$\mathrm{Zn}$-fertilizer applications. These $\mathrm{Zn}$ concentrations approach that found in raw beefsteak, which approximates $200-250 \mathrm{mg} \mathrm{Zn} \mathrm{kg}$ DM (U.S. Department of Agriculture, Agricultural Research Service, 2011). By contrast, $\mathrm{Zn}$ concentrations in fruits, seeds, and tubers are severely limited by $\mathrm{Zn}$ transport in the phloem. This might be a consequence of the need to maintain low $\mathrm{Zn}^{2+}$ concentrations in phloem sap to avoid cellular toxicity. Increased production of compounds that chelate $\mathrm{Zn}^{2+}$, such as NA, can increase $\mathrm{Zn}$ concentrations in the phloem and its delivery to phloem-fed tissues. Agrochemicals that increase the concentrations of $\mathrm{Zn}$-complexes in the phloem might be used to increase $\mathrm{Zn}$ concentrations in fruits, seeds, and tubers. Thus, application of $\mathrm{Zn}$-fertilizers, especially in combination with nitrogen fertilizers, can increase $\mathrm{Zn}$ concentrations in seeds of cereals to about $100 \mathrm{mg} \mathrm{kg}^{-1} \mathrm{DM}$ and $\mathrm{Zn}$ concentrations in seeds of legumes to about $120 \mathrm{mg} \mathrm{kg}^{-1} \mathrm{DM}$ (see Agronomic Strategies to Increase Zinc Concentrations of Edible Crops).

Since there is appreciable variation in $\mathrm{Zn}$ concentrations of edible tissues of food crops, conventional breeding for increased Zn concentrations appears feasible (see Genetic Variation in Zinc Concentrations of Edible Crops). It is possible that breeding can increase $\mathrm{Zn}$-tolerance in root and leaf crops and increase $\mathrm{Zn}$ mobility in the phloem in fruit, seed, and tuber crops. Improving $\mathrm{Zn}$ tolerance in root and leaf crops and increasing phloem Zn mobility in fruit, seed, and tuber crops might also be addressed through GM technologies (see Genetic Modification Strategies for Zinc Biofortification of Edible Crops). Several transgenic crop plants have been created that have greater $\mathrm{Zn}$ concentrations in their edible tissues than conventional varieties. These include cassava roots with about $40 \mathrm{mg} \mathrm{Zn} \mathrm{kg}^{-1} \mathrm{DM}$ (Sayre et al., 2011), brown rice with 5695 mg Zn kg ${ }^{-1}$ DM (Vasconcelos et al., 2003; Johnson et al., 2011), and barley grain with $85 \mathrm{mg} \mathrm{Zn} \mathrm{kg}^{-1} \mathrm{DM}$ (Ramesh et al., 2004). Nevertheless, it is possible that the general homeostatic regulation of tissue $\mathrm{Zn}$ concentrations through $\mathrm{Zn}$ acquisition and distribution within the plant could be a major constraint to increasing $\mathrm{Zn}$ concentrations in edible portions (see Plant Physiology). A critical role of $\mathrm{Zn}$ in plant cells is the control of transcription, translation, and protein activity through cytoplasmic $\mathrm{Zn}^{2+}$ concentration (Broadley et al., 2007). The key to Zn-homeostasis in plant cells is likely, therefore, to pivot on cytoplasmic $\mathrm{Zn}^{2+}$ concentration. Increasing tissue $\mathrm{Zn}$ concentrations will require increased biosynthesis of $\mathrm{Zn}$-complexes and effective sequestration of $\mathrm{Zn}$ in non-vital compartments, such as the vacuole, to avoid unwanted perturbations in cytoplasmic $\mathrm{Zn}^{2+}$ concentration. For this, lessons might be learnt from $\mathrm{Zn}$-hyperaccumulator plants.

To increase $\mathrm{Zn}$ concentrations in edible crops, future research should focus on (i) integrating agronomic and genetic strategies to increase $\mathrm{Zn}$ transport to phloem-fed tissues and (ii) identifying the mechanisms effecting $\mathrm{Zn}$-homeostasis in plant cells and strategies to manage subcellular Zn compartmentalization.

\section{ACKNOWLEDGMENTS}

This work was supported by the Rural and Environment Science and Analytical Services Division (RESAS) of the Scottish Government through Workpackage 7.2 (2011-2016). 


\section{REFERENCES}

Agbor-Egbe, T., and Trèche, S. (1995). Evaluation of the chemical composition of Cameroonian yam germplasm. J. Food Compost. Anal. 8, 274-283.

Arrivault, S., Senger, T., and Krämer, U. (2006). The Arabidopsis metal tolerance protein AtMTP3 maintains metal homeostasis by mediating $\mathrm{Zn}$ exclusion from the shoot under Fe deficiency and Zn oversupply. Plant J. 46, 861-879.

Assunção, A. G. L., Herrero, E., Lin, Y.-F., Huettel, B., Talukdar, S., Smaczniak, C., Immink, R. G. H., van Eldik, M., Fiers, M., Schat, H., and Aarts, M. G. M. (2010). Arabidopsis thaliana transcription factors bZIP19 and bZIP23 regulate the adaptation to zinc deficiency. Proc. Natl. Acad. Sci. U.S.A. 107, 10296-10301.

Bänziger, M., and Long, J. (2000). The potential for increasing the iron and zinc density of maize through plant-breeding. Food Nutr. Bull. 21, 397-400.

Bennett, L. E., Burkhead, J. L., Hale, K. L., Terry, N., Pilon, M., and PilonSmits, E. A. H. (2003). Analysis of transgenic Indian mustard plants for phytoremediation of metalcontaminated mine tailings. J. Environ. Qual. 32, 432-440.

Blair, M., Astudillo, C., Grusak, M., Graham, R., and Beebe, S. (2009). Inheritance of seed iron and zinc concentrations in common bean (Phaseolus vulgaris L.). Mol. Breed. 23, 197-207.

Blair, M. W., Astudillo, C., Rengifo, J., Beebe, S. E., and Graham, R. (2011). QTL analyses for seed iron and zinc concentrations in an intra-genepool population of Andean common beans (Phaseolus vulgaris L.). Theor. Appl. Genet. 122, 511-521.

Blair, M. W., Medina, J. I., Astudillo, C., Rengifo, J., Beebe, S. E., Machado, G., and Graham, R. (2010). QTL for seed iron and zinc concentration and content in a Mesoamerican common bean (Phaseolus vulgaris L.) population. Theor. Appl. Genet. 121, 1059-1070.

Bouis, H. E., and Welch, R. M. (2010). Biofortification - a sustainable agricultural strategy for reducing micronutrient malnutrition in the global South. Crop Sci. 50, S20S32.

Branch, W. D., and Gaines, T. P. (1983). Seed mineral composition of diverse peanut germplasm. Peanut Sci. 10, 5-8.

Broadley, M., Brown, P., Cakmak, I., Rengel, Z., and Zhao, F. (2012). "Function of nutrients: micronutrients," in Marschner's Mineral Nutrition of Higher Plants, 3rd Edn, ed. P. Marschner (London: Academic Press), 191-248.

Broadley, M. R., White, P. J., Hammond, J. P., Zelko, I., and Lux, A. (2007). Zinc in plants. New Phytol. 173, 677-702.

Broadley, M. R., Willey, N. J., Wilkins, J. C., Baker, A. J. M., Mead, A., and White, P. J. (2001). Phylogenetic variation in heavy metal accumulation in angiosperms. New Phytol. 152, 9-27.

Broadley, M. R., O Lochlainn, S., Hammond, J. P., Bowen, H. C., Çakmak, I., Eker, S., Erdem, H., King, G. J., and White, P. J. (2010). Shoot zinc (Zn) concentration varies widely within Brassica oleracea L. and is affected by soil $\mathrm{Zn}$ and phosphorus (P) levels. $J$. Hortic. Sci. Biotechnol. 85, 375-380.

Brown, P. (2009). "Development of a model system for testing foliar fertilizers, adjuvants and growth stimulants," in Proceedings of the California Department of Food and Agriculture Fertilizer Research and Education Program Conference 2008, Visalia, CA, 17-23.

Cakmak, I. (2004). "Identification and Correction of Widespread Zinc Deficiency in Turkey - A Success Story," in Proceedings of the International Fertiliser Society 552 (York: International Fertiliser Society).

Cakmak, I. (2008). Enrichment of cereal grains with zinc: agronomic or genetic biofortification? Plant Soil 302, 1-17.

Cakmak, I. (2009). Enrichment of fertilizers with zinc: an excellent investment for humanity and crop production in India. J. Trace Elem. Med. Biol. 23, 281-289.

Cakmak, I., Kalayci, M., Ekiz, H., Braun, H. J., Kilinc, Y., and Yilmaz, A. (1999). Zinc deficiency as a practical problem in plant and human nutrition in Turkey: a NATO-science for stability project. Field Crops Res. 60, 175-188.

Cakmak, I., Kalayci, M., Kaya, Y., Torun, A. A., Aydin, N., Wang, Y., Arisoy, Z., Erdem, H., Yazici, A., Gokmen, O., Ozturk, L., and Horst, W. J. (2010a). Biofortification and localization of zinc in wheat grain. J. Agric. Food Chem. 58, 9092-9102.

Cakmak, I., Pfeiffer, W. H., and McClafferty, B. (2010b). Biofortification of durum wheat with zinc and iron. Cereal Chem. 87, 10-20.

Chávez, A. L., Sánchez, T., Jaramillo, G., Bedoya, J. M., Echeverry, J., Bolaños, E. A., Ceballos, H., and Iglesias, C. A. (2005). Variation of quality traits in cassava roots evaluated in landraces and improved clones. Euphytica 143, 125-133.

Cichy, K. A., Caldas, G. V., Snapp, S. S., and Blair, M. W. (2009). QTL analysis of seed iron, zinc, and phosphorus levels in an Andean bean population. Crop Sci. 49, 1742-1750.

Cichy, K. A., Forster, S., Grafton, K. F., and Hosfield, G. L. (2005). Inheritance of seed zinc accumulation in navy bean. Crop Sci. 45, 864-870.

Clemens, S. (2010). “ $\mathrm{Zn} \mathrm{-} \mathrm{a} \mathrm{versatile}$ player in plant cell biology," in Plant Cell Monographs 17, Cell Biology of Metals and Nutrients, eds R. Hell and R. R. Mendel (Berlin: Springer), 281-298.

Curie, C., Cassin, G., Couch, D., Divol, F., Higuchi, K., Le Jean, M., Misson, J., Schikora, A., Czernic, P., and Mari, S. (2009). Metal movement within the plant: contribution of nicotianamine and yellow stripe 1-like transporters. Ann. Bot. 103, $1-11$.

Davey, M. W., Stals, E., NgohNewilah, G., Tomekpe, K., Lusty, C., Markham, R., Swennen, R., and Keulemans, J. (2007). Sampling strategies and variability in fruit pulp micronutrient contents of West and Central African bananas and plantains (Musa species). J. Agric. Food Chem. 55, 2633-2644.

Davis, D. R. (2011). "Impact of breeding and yield on fruit, vegetable, and grain nutrient content," in Breeding for Fruit Quality, eds M. A. Jenks and P. J. Bebeli (New York: John Wiley \& Sons), 49-70.

Demidchik, V., Bowen, H. C., Maathuis, F. J. M., Shabala, S. N., Tester, M. A., White, P. J., and Davies, J. M. (2002). Arabidopsis thaliana root nonselective cation channels mediate calcium uptake and are involved in growth. Plant J. 32, 799-808.

Department of Health (UK). (1991). Report on Health and Social Subjects 41. Dietary Reference Values for Food Energy and Nutrients. London: HMSO.

Distelfeld, A., Cakmak, I., Peleg, Z., Ozturk, L., Yazici, A. M., Budak, H., Saranga, Y., and Fahima, T. (2007). Multiple QTL-effects of wheat GpcB1 locus on grain protein and micronutrient concentrations. Physiol. Plant 129, 635-643.

Eren, E., and Argüello, J. M. (2004). Arabidopsis HMA2, a divalent heavy metal-transporting PIB-type ATPase, is involved in cytoplasmic $\mathrm{Zn}^{2+}$ homeostasis. Plant Physiol. 136, 3712-3723.

Fageria, N. K. (2009). The Use of Nutrients in Crop Plants. Boca Raton, FL: CRC Press.
Fang, Y., Wang, L., Xin, Z., Zhao, L., An, X., and Hu, Q. (2008). Effect of foliar application of zinc, selenium, and iron fertilizers on nutrients concentration and yield of rice grain in China. J. Agric. Food Chem. 56, 2079-2084.

Frey, B., Keller, C., Zierold, K., and Schulin, R. (2000). Distribution of $\mathrm{Zn}$ in functionally different leaf epidermal cells of the hyperaccumulator Thlaspi caerulescens. Plant Cell Environ. 23, 675-687.

Garvin, D. F., Welch, R. M., and Finley, J. W. (2006). Historical shifts in the seed mineral micronutrient concentration of US hard red winter wheat germplasm. J. Sci. Food Agric. 86, 2213-2220.

Gelin, J. P., Forster, S., Grafton, K. F., McClean, P. E., and Kooas-Cifuentes, G. A. (2007). Analysis of seed zinc and other minerals in a recombinant inbred population of navy bean (Phaseolus vulgaris L.). Crop Sci. 47, 1361-1366.

Genc, Y., Verbyla, A., Torun, A., Cakmak, I., Willsmore, K., Wallwork, H., and McDonald, G. (2009). Quantitative trait loci analysis of zinc efficiency and grain zinc concentration in wheat using whole genome average interval mapping. Plant Soil 314, 49-66.

Gomez-Becerra, H. F., Erdem, H., Yazici, A., Tutus, Y., Torun, B., Ozturk, L., and Cakmak, I. (2010). Grain concentrations of protein and mineral nutrients in a large collection of spelt wheat grown under different environments. J. Cereal Sci. 52, 342-349.

Graham, R., Senadhira, D., Beebe, S., Iglesias, C., and Monasterio, I. (1999). Breeding for micronutrient density in edible portions of staple food crops: conventional approaches. Field Crops Res. 60, 57-80.

Graham, R. D., Welch, R. M., and Bouis, H. E. (2001). Addressing micronutrient malnutrition through enhancing the nutritional quality of staple foods: principles, perspectives and knowledge gaps. Adv. Agron. 70, 77-142.

Graham, R. D., Welch, R. M., Saunders, D. A., Ortiz-Monasterio, I., Bouis, H. E., Bonierbale, M., de Haan, S., Burgos, G., Thiele, G., Liria, R., Meisner, C. A., Beebe, S. E., Potts, M. J., Kadian, M., Hobbs, P. R., Gupta, R. K., and Twomlow, S. (2007). Nutritious subsistence food systems. $A d v$. Agron. 92, 1-74.

Gregorio, G. B., Senadhira, D., Htut, H., and Graham, R. D. (2000). Breeding for trace mineral density in rice. Food Nutr. Bull. 21, 382-386. 
Grusak, M. A., and Cakmak, I. (2005). "Methods to improve the cropdelivery of minerals to humans and livestock," in Plant Nutritional Genomics, eds M. R. Broadley and P. J. White (Oxford: Blackwell), 265-286.

Gustin, J. L., Loureiro, M. E., Kim, D., Na, G., Tikhonova, M., and Salt, D. E. (2009). MTP1-dependent $\mathrm{Zn}$ sequestration into shoot vacuoles suggests dual roles in $\mathrm{Zn}$ tolerance and accumulation in $\mathrm{Zn}$ hyperaccumulating plants. Plant $J$. 57, 1116-1127.

Guzmán-Maldonado, S. H., Martínez, O., Acosta-Gallegos, J. A., GuevaraLara, F., and Paredes-López, O. (2003). Putative quantitative trait loci for physical and chemical components of common bean. Crop Sci. 43, 1029-1035.

Hakala, M., Lapveteläinen, A., Houpalahti, R., Kallio, H., and Tahvonen, R. (2003). Effects of varieties and cultivation conditions on the composition of strawberries. J. Food Compost. Anal. 16, 67-80.

Hammond, J. P., Bowen, H. C., White, P. J., Mills, V., Pyke, K. A., Baker, A. J. M., Whiting, S. N., May, S. T., and Broadley, M. R. (2006). A comparison of the Thlaspi caerulescens and Thlaspi arvense shoot transcriptomes. New Phytol. 170, 239-260.

Hanikenne, M., Talke, I. N., Haydon, M. J., Lanz, C., Nolte, A., Motte, P., Kroymann, J., Weigel, D., and Kramer, U. (2008). Evolution of metal hyperaccumulation required cis-regulatory changes and triplication of HMA4. Nature 453, 391-395.

Hansen, T. H., Laursen, K. H., Persson, D. P., Pedas, P., Husted, S., and Schoerring, J. K. (2009). Micro-scaled high-throughput digestion of plant tissue samples for multi-elemental analysis. Plant Methods 5, 12.

Hao, H.-L., Wei, Y.-Z., Yang, X.-E., Feng, Y., and Wu, C.-Y. (2007). Effects of different nitrogen fertilizer levels on $\mathrm{Fe}, \mathrm{Mn}, \mathrm{Cu}$ and $\mathrm{Zn}$ concentrations in shoot and grain quality in rice (Oryza sativa). Rice Sci. 14, 289-294.

Haslett, B. S., Reid, R. J., and Rengel, Z. (2001). Zinc mobility in wheat: uptake and distribution of zinc applied to leaves or roots. Ann. Bot. 87, 379-386.

Hassan, Z., and Aarts, M. G. M. (2011). Opportunities and feasibilities for biotechnological improvement of $\mathrm{Zn}, \mathrm{Cd}$ or Ni tolerance and accumulation in plants. Environ. Exp. Bot. $72,53-63$.

$\mathrm{He}, \mathrm{X}$., and Nara, K. (2007). Element biofortification: can mycorrhizas potentially offer a more effective and sustainable pathway to curb human malnutrition? Trends Plant Sci. 12, 331-333.

Hlusek, J., Juzl, M., and Zrust, J. (1997). Potato yields and cadmium, nickel and zinc contents in tubers. Rostlinna Vyroba 43, 263-267.

Horton, S. (2006). The economics of food fortification. J. Nutr. 136, 1068-1071.

Hotz, C., and Brown, K. H. (2004). International Zinc Nutrition Consultative Group. Technical Document \#1 Assessment of the risk of inc deficiency in populations and options for its control. Food Nutr. Bull. 25, S91-S203.

Ibrikci, H., Knewtson, S. J. B., and Grusak, M. A. (2003). Chickpea leaves as a vegetable green for humans: evaluation of mineral composition. J. Sci. Food Agric. 83, 945-950.

Institute of Medicine (USA). (2001). Dietary Reference Intakes for Vitamin A, Vitamin K, (Arsenic), Boron, Chromium, Copper, Iodine, Iron, Manganese, Molybdenum, Nickel, Silicon, Vanadium, and Zinc. Washington, DC: National Academies Press.

Ishimaru, Y., Masuda, H., Suzuki, M., Bashir, K., Takahashi, M., Nakanishi, H., Mori, S., and Nishizawa, N. K. (2007). Overexpression of the OsZIP4 zinc transporter confers disarrangement of zinc distribution in rice plants. J. Exp. Bot. 58, 2909-2915.

Islam, F. M. A., Basford, K. E., Jara, C., Redden, R. J., and Beebe, S. (2002). Seed compositional and disease resistance differences among gene pools in cultivated common bean. Genetic Resour. Crop Evol. 49, 285-293.

Iwane, A. (1991). Effect of cultivar and year on mineral components of apples. J. Jpn. Soc. Food Sci. Technol. $38,329-336$.

Jarrell, W. M., and Beverly, R. B. (1981). The dilution effect in plant nutrition studies. Adv. Agron. 34, 197-224.

Jiang, W., Struik, P. C., van Keulen, H., Zhao, M., Jin, L. N., and Stomph, T. J. (2008), Does increased zinc uptake enhance grain zinc mass concentration in rice? Ann. Appl. Biol. 153, 135-147.

Johnson, A. A. T., Kyriacou, B., Callahan, D. L., Carruthers, L., Stangoulis, J., Lombi, E., and Tester, M. (2011). Constitutive overexpression of the OsNAS gene family reveals singlegene strategies for effective ironand zinc-biofortification of rice endosperm. PLoS ONE 6, e24476. doi:10.1371/journal.pone.0024476

Khoshgoftarmanesh, A. H., Schulin, R., Chaney, R. L., Daneshbakhsh, B., and
Afyuni, M. (2009). Micronutrientefficient genotypes for crop yield and nutritional quality in sustainable agriculture. A review. Agron. Sustain. Dev. 30, 83-107.

Kopittke, P. M., Menzies, N. W., de Jonge, M. D., McKenna, B. A., Donner, E., Webb, R. I., Paterson, D. J. Howard, D. L., Ryan, C. G., Glover, C. J., Scheckel, K. G., and Lombi, E. (2011). In situ distribution and speciation of toxic copper, nickel, and zinc in hydrated roots of cowpea. Plant Physiol. 156, 663-673.

Krämer, U. (2010). Metal hyperaccumulation in plants. Annu. Rev. Plant Biol. 61, 517-534.

Küpper, H., Lombi, E., Zhao, F.-J., and McGrath, S. P. (2000). Cellular compartmentation of cadmium and zinc in relation to other elements in the hyperaccumulator Arabidopsis halleri. Planta 212, 75-84.

Küpper, H., Mijovilovich, A., MeyerKlaucke, W., and Kroneck, P. M. H. (2004). Tissue- and agedependent differences in the complexation of cadmium and zinc in the cadmium/zinc hyperaccumulator Thlaspicaerulescens (Ganges ecotype) revealed by X-ray absorption spectroscopy. Plant Physiol. 134 748-757.

Küpper, H., Zhao, F. J., and McGrath, S. P. (1999). Cellular compartmentation of zinc in leaves of the hyperaccumulator Thlaspi caerulescens. Plant Physiol. 119, 305-311.

Kutman, U. B., Yildiz, B., and Cakmak, I. (2011a). Improved nitrogen status enhances zinc and iron concentrations both in the whole grain and the endosperm fraction of wheat. $J$. Cereal Sci. 53, 118-125.

Kutman, U. B., Yildiz, B., and Cakmak, I. (2011b). Effect of nitrogen on uptake, remobilization and partitioning of zinc and iron throughout the development of durum wheat. Plant Soil 342, 149-164.

Kutman, U. B., Yildiz, B., Ozturk, L., and Cakmak, I. (2010). Biofortification of durum wheat with zinc through soil and foliar applications of nitrogen. Cereal Chem. 87, 1-9.

Lee, S., Jeon, U. S., Lee, S. J., Kim, Y. K., Persson, D. P., Husted, S., Schjorring, J. K., Kakei, Y., Masuda, H., Nishizawa, N. K., and An, G. (2009). Iron fortification of rice seeds through activation of the nicotianamine synthase gene. Proc. Natl. Acad. Sci. U.S.A. 106, 22014-22019.

Lee, S., Jeong, H. J., Kim, S. A., Lee, J., Guerinot, M., and An, G. (2010). OsZIP5 is a plasma membrane zinc transporter in rice. Plant Mol. Biol. 73, 507-517.

Lee, S., Persson, D. P., Hansen, T. H., Husted, S., Schjoerring, J. K., Kim,
Y.-S., Jeon, U. S., Kim, Y.-K., Kakei, Y, Masuda, H., Nishizawa, N. K., and An, G. (2011). Bio-available zinc in rice seeds is increased by activation tagging of nicotianamine synthase. Plant Biotechnol. J. 9, 865-873.

Lin, L., Ockenden, I., and Lott, J. N. A. (2005). The concentrations and distribution of phytic acid-phosphorus and other mineral nutrients in wildtype and low phytic acid1-1 (lpa1-1) corn (Zea mays L.) grains and grain parts. Can. J. Bot. 83, 131-141.

Liu, K., Peterson, K. L., and Raboy, V. (2007). Comparison of the phosphorus and mineral concentrations in bran and abraded kernel fractions of a normal barley (Hordeum vulgare) cultivar versus four low phytic acid isolines. J. Agric. Food Chem. 55, 4453-4460.

Lombi, E., Smith, E., Hansen, T. H., Paterson, D., de Jonge, M. D., Howard, D. L., Persson, D. P., Husted, S., Ryan, C., and Schjoerring, J. K. (2011). Megapixel imaging of (micro)nutrients in mature barley grains. J. Exp. Bot. 62, 273-282.

Lonergan, P. F., Pallotta, M. A., Lorimer, M., Paull, J. G., Barker, S. J., and Graham, R. D. (2009). Multiple genetic loci for zinc uptake and distribution in barley (Hordeum vulgare). New Phytol. 184, 168-179.

Ma, G., Jin, Y., Li, Y., Zhai, F., Kok, F. J., Jacobsen, E., and Yang, X. (2008). Iron and zinc deficiencies in China: what is a feasible and cost-effective strategy? Public Health Nutr. 11, 632-638.

Ma, J. F., Ueno, D., Zhao, F.-J., and McGrath, S. P. (2005). Subcellular localisation of $\mathrm{Cd}$ and $\mathrm{Zn}$ in the leaves of a Cd-hyperaccumulating ecotype of Thlaspi caerulescens. Planta 220, 731-736.

MacNicol, R. D., and Beckett, P. H. T. (1985). Critical tissue concentrations of potentially toxic elements. Plant Soil 85, 107-129.

Martínez-Ballesta, M. C., DominguezPerles, R., Moreno, D. A., Muries, B., Alcaraz-López, C., Bastías, E., García-Viguera, C., and Carvajal, M. (2010). Minerals in plant food: effect of agricultural practices and role in human health. A review. Agron. Sustain. Dev. 30, 295-309.

Meenakshi, J. V., Johnson, N. L., Manyong, V. M., Degroote, H., Javelosa, J., Yanggen, D. R., Naher, F., Gonzalez, C., García, J., and Meng, E. (2010). How cost-effective is biofortification in combating micronutrient malnutrition? An ex ante assessment. World Dev. 38, 64-75.

Monasterio, I., and Graham, R. D. (2000). Breeding for trace minerals in wheat. Food Nutr. Bull. 21 392-396. 
Monsant, A. C., Kappen, P., Wang, Y., Pigram, P. J., Baker, A. J. M., and Tang, C. (2011). In vivo speciation of zinc in Noccaea caerulescens in response to nitrogen form and zinc exposure. Plant Soil 348, 167-183.

Monsant, A. C., Wang, Y., and Tang, C. (2010). Nitrate nutrition enhances zinc hyperaccumulation in Noccaea caerulescens (Prayon). Plant Soil 336, 391-404.

Murphy, K. M., Reeves, P. G., and Jones, S. S. (2008). Relationship between yield and mineral nutrient concentrations in historical and modern spring wheat cultivars. Euphytica 163, 381-390.

Nicolle, C., Simon, G., Rock, E., Amouroux, P., and Rémésy, C. (2004). Genetic variability influences carotenoid, vitamin, phenolic, and mineral content in white, yellow, purple, orange, and dark-orange carrot cultivars. J. Am. Soc. Hortic. Sci. 129, 523-529.

Ó Lochlainn, S., Bowen, H. C., Fray, R. G., Hammond, J. P., King, G. J., White, P. J., and Broadley, M. R. (2011). Tandem quadruplication of HMA4 in the zinc $(\mathrm{Zn})$ and cadmium (Cd) hyperaccumulator Noccaea caerulescens. PLoS ONE 6, e17814. doi:10.1371/journal.pone.0017814

Ozturk, L., Yazici, M. A., Yucel, C., Torun, A., Cekic, C., Bagci, A., Ozkan, H., Braun, H.-J., Sayers, Z., and Cakmak, I. (2006). Concentration and localization of zinc during seed development and germination in wheat. Physiol. Plant 128 , 144-152.

Palmer, C. M., and Guerinot, M. L. (2009). Facing the challenges of $\mathrm{Cu}$, $\mathrm{Fe}$ and $\mathrm{Zn}$ homeostasis in plants. Nat. Chem. Biol. 5, 333-340.

Peleg, Z., Cakmak, I., Ozturk, L., Yazici, A., Jun, Y., Budak, H., Korol, A. B., Fahima, T., and Saranga, Y. (2009). Quantitative trait loci conferring grain mineral nutrient concentrations in durum wheat $\mathrm{x}$ wild emmer wheat RIL population. Theor. Appl. Genet. 119, 353-369.

Persson, D. P., Hansen, T. H., Laursen, K. H., Schjoerring, J. K., and Husted, S. (2009). Simultaneous iron, zinc, sulfur and phosphorus speciation analysis of barley grain tissues using SEC-ICP-MS and IP-ICP-MS. Metallomics 1, 418-426.

Pfeiffer, W. H., and McClafferty, B. (2007). HarvestPlus: breeding crops for better nutrition. Crop Sci. 47, S88-S105.

Puig, S., and Peñarrubia, L. (2009). Placing metal micronutrients in context: transport and distribution in plants. Curr. Opin. Plant Biol. 12, 299-306.
Raboy, V., Dickinson, D. B., and Below, F. E. (1984). Variation in seed total phosphorus, phytic acid, zinc, calcium, magnesium and protein among lines of Glycine max and $G$. soja. Crop Sci. 24, 431-434.

Ramesh, S. A., Choimes, S., and Schachtman, D. P. (2004). Overexpression of an Arabidopsis zinc transporter in Hordeum vulgare increases short-term zinc uptake after zinc deprivation and seed zinc content. Plant Mol. Biol. 54, 373-385.

Rascio, N., and Navari-Izzo, F. (2011). Heavy metal hyperaccumulating plants: how and why do they do it? And what makes them so interesting? Plant Sci. 180, 169-181.

Reddy, B. V. S., Ramesh, S., and Longvah, T. (2005). Prospects of breeding for micronutrients and $\beta$-carotenedense sorghums. Int. Sorghum Millets Newsl. 46, 10-14.

Reeves, R. D., and Baker, A. J. M. (2000). "Metal-accumulating plants," in Phytoremediation of Toxic Metals: Using Plants to Clean Up the Environment, eds I. Raskin and B. D. Ensley (New York: John Wiley \& Sons), 193-229.

Reichman, S. M. (2002). The Responses of Plants to Metal Toxicity: A Review Focusing on Copper, Manganese and Zinc. Melbourne: Australian Minerals and Energy Environment Foundation.

Rengel, Z., Batten, G. D., and Crowley, D. E. (1999). Agronomic approaches for improving the micronutrient density in edible portions of field crops. Field Crops Res. 60, 27-40.

Rogers, E. E., and Guerinot, M. L. (2002). FRD3, a member of the multidrug and toxin efflux family, controls iron deficiency responses in Arabidopsis. Plant Cell 14, 1787-1799.

Roosens, N. H. C. J., Willems, G., and Saumitou-Laprade, P. (2008). Using Arabidopsis to explore zinc tolerance and hyperaccumulation. Trends Plant Sci. 13, 208-215.

Sagardoy, R., Morales, F., López-Millán, A. F., Abadía, A., and Abadía, J. (2009). Effects of zinc toxicity on sugar beet (Beta vulgaris L.) plants grown in hydroponics. Plant Biol. 11, 339-350.

Salt, D. E., Prince, R. C., Baker, A. J. M., Raskin, I., and Pickering, I. J. (1999). Zinc ligands in the metal hyperaccumulator Thlaspi caerulescens as determined using X-ray absorption spectroscopy. Environ. Sci. Technol. 33, 713-717.

Sarret, G., Willems, G., Isaure, M.P., Marcus, M. A., Fakra, S. C., Frérot, H., Pairis, S., Geoffroy,
N., Manceau, A., and SaumitouLaprade, P. (2009). Zinc distribution and speciation in Arabidopsis halleri $\times$ Arabidopsis lyrata progenies presenting various zinc accumulation capacities. New Phytol. 184, 581-595.

Sayre, R., Beeching, J. R., Cahoon, E. B., Egesi, C., Fauquet, C., Fellman, J., Fregene, M., Gruissem, W., Mallowa, S., Manary, M., Maziya-Dixon, B., Mbanaso, A., Schachtman, D. P., Siritunga, D., Taylor, N., Vanderschuren, H., and Zhang, P. (2011). The BioCassava Plus Program: biofortification of Cassava for Sub-Saharan Africa. Annu. Rev. Plant Biol. 62, 251-272.

Shi, R., Zhang, Y., Chen, X., Sun, Q., Zhang, F., Römheld, V., and Zou, C. (2010). Influence of long-term nitrogen fertilization on micronutrient density in grain of winter wheat (Triticum aestivum L.). J. Cereal Sci. 51, 165-170.

Stacey, M. G., Patel, A., McClain, W. E., Mathieu, M., Remley, M., Rogers, E. E., Gassmann, W., Blevins, D. G., and Stacey, G. (2008). The Arabidopsis AtOPT3 protein functions in metal homeostasis and movement of iron to developing seeds. Plant Physiol. 146, 589-601.

Stangoulis, J. C. R., Huynh, B. L., Welch, R. M., Choi, E. Y., and Graham, R. D. (2007). Quantitative trait loci for phytate in rice grain and their relationship with grain micronutrient content. Euphytica 154, 289-294.

Stein, A. J. (2010). Global impacts of human mineral malnutrition. Plant Soil 335, 133-154

Stein, A. J., Meenakshi, J. V., Qaim, M., Nestel, P., Sachdev, H. P. S., and Bhutta, Z. A. (2005). Technical Monograph 4. Analysing the Health Benefits of Biofortified Staple Crops by Means of the Disability-Adjusted Life Years Approach: A Handbook Focusing on Iron, Zinc and Vitamin A. Washington, WA: HarvestPlus.

Stein, A. J., Nestel, P., Meenakshi, J. V., Qaim, M., Sachdev, H. P. S., and Bhutta, Z. A. (2007). Plant breeding to control zinc deficiency in India: how cost-effective is biofortification? Public Health Nutr. 10, 492-501.

Stomph, T. J., Choi, E. Y., and Stangoulis, J. C. R. (2011). Temporal dynamics in wheat grain zinc distribution: is sink limitation the key? Ann. Bot. 107, 927-937.

Stomph, T. J., Jiang, W., and Struik, P. C. (2009). Zinc biofortification of cereals, rice differs from wheat and barley. Trends Plant Sci. 14, 123-124.
Straczek, A., Sarret, G., Manceau, A., Hinsinger, P., Geoffroy, N., and Jaillard, B. (2008). Zinc distribution and speciation in roots of various genotypes of tobacco exposed to $\mathrm{Zn}$. Environ. Exp. Bot. 63, 80-90.

Subramanian, N. K., White, P. J., Broadley, M. R., and Ramsay, G. (2011). The three-dimensional distribution of minerals in potato tubers. Ann. Bot. 107, 681-691.

Suzuki, M., Morikawa, K. C., Nakanishi, H., Takahashi, M., Saigusa, M., Mori, S., and Nishizawa, N. K. (2008). Transgenic rice lines that include barley genes have increased tolerance to low iron availability in a calcareous paddy soil. Soil Sci. Plant Nutr. 54, 77-85.

Takahashi, M., Terada, Y., Nakai, I., Nakanishi, H., Yoshimura, E., Mori, S., and Nishizawa, N. K. (2003). Role of nicotianamine in the intracellular delivery of metals and plant reproductive development. Plant Cell 15, 1263-1280.

Tappero, R., Peltier, E., Gräfe, M., Heidel, K., Ginder-Vogel, M., Livi, K. J. T., Rivers, M. L., Marcus, M. A., Chaney, R. L., and Sparks, D. L. (2007). Hyperaccumulator Alyssum murale relies on a different metal storage mechanism for cobalt than for nickel. New Phytol. 175, 641-634.

Terzano, R., Chami, Z. A., Vekemans, B., Janssens, K., Miano, T., and Ruggiero, P. (2008). Zinc distribution and speciation within rocket plants (Eruca vesicaria L. Cavalieri) grown on a polluted soil amended with compost as determined by XRF microtomography and microXANES. J. Agric. Food Chem. 56, 3222-3231.

Uauy, C., Distelfeld, A., Fahima, T., Blechl, A., and Dubcovsky, J. (2006). A NAC gene regulating senescence improves grain protein, zinc, and iron content in wheat. Science 314, 1298-1301.

U.S. Department of Agriculture, Agricultural Research Service (USDA-ARS). (2011). USDA National Nutrient Database for Standard Reference, Release 24. Nutrient Data Laboratory. Available at: http://www.ars.usda.gov/ba/bhnrc/ndl [accessed October 10, 2011].

van der Zaal, B. J., Neuteboom, L. W., Pinas, J. E., Chardonnens, A. N., Schat, H., Verkleij, J. A. C., and Hooykaas, P. J. J. (1999). Overexpression of a novel Arabidopsis gene related to putative zinctransporter genes from animals can lead to enhanced zinc resistance and accumulation. Plant Physiol. 119, 1047-1056 
Van Steveninck, R. F. M., Babare, A., Fernando, D. R., and Van Steveninck, M. E. (1994). The binding of zinc, but not cadmium, by phytic acid in roots of crop plants. Plant Soil 167, 157-164.

Vasconcelos, M., Datta, K., Oliva, N., Khalekuzzaman, M., Torrizo, L., Krishnan, S., Oliveira, M., Goto, F., and Datta, S. K. (2003). Enhanced iron and zinc accumulation in transgenic rice with the ferritin gene. Plant Sci. 164, 371-378.

Vázquez, M. D., Poschenrieder, C., Barceló, J., Baker, A. J. M., Hatton, P., and Cope, G. L. (1994). Compartmentation of zinc in roots and leaves of the zinc hyperaccumulator Thlaspi caerulescens J \& C Presl. Bot. Acta 107, 243-250.

Velu, G., Rai, K. N., Muralidharan, V., Kulkarni, V. N., Longvah, T., and Raveendran, T. S. (2007). Prospects of breeding biofortified pearl millet with high grain iron and zinc content. Plant Breed. 126, 182-185.

Verbruggen, N., Hermans, C., and Schat, H. (2009). Molecular mechanisms of metal hyperaccumulation in plants. New Phytol. 181, 759-776.

Verret, F., Gravot, A., Auroy, P., Leonhardt, N., David, P., Nussaume, L., Vavasseur, A., and Richaud, P. (2004). Overexpression of AtHMA4 enhances root-to-shoot translocation of zinc and cadmium and plant metal tolerance. FEBS Lett. 576, 306-312.

Watanabe, T., Broadley, M. R., Jansen, S., White, P. J., Takada, J., Satake, K., Takamatsu, T., Tuah, S. J., and Osaki, M. (2007). Evolutionary control of leaf element composition in plants. New Phytol. 174, 516-523.

Waters, B. M., and Grusak, M. A. (2008). Whole-plant mineral partitioning throughout the life cycle in Arabidopsis thaliana ecotypes Columbia, Landsberg erecta, Cape Verde Islands, and the mutant line ysllysl3. New Phytol. 177, 389-405.

Waters, B. M., and Sankaran, R. P. (2011). Moving micronutrients from the soil to the seeds: genes and physiological processes from a biofortification perspective. Plant Sci. 180, 562-574.

Welch, R. M. (1995). Micronutrient nutrition of plants. CRC Crit. Rev. Plant Sci. 14, 49-82.

White, P. J. (2012a). "Long-distance transport in the xylem and phloem," in Marschner's Mineral Nutrition of Higher Plants, 3rd Edn, ed. P. Marschner (London: Academic Press), 49-70.

White, P. J. (2012b). "Heavy metal toxicity in plants," in Plant Stress Physiology, ed. S. Shabala (Wallingford: $\mathrm{CABI}$ ), (in press).

White, P. J., Bowen, H. C., Demidchik, V., Nichols, C., and Davies, J. M. (2002a). Genes for calciumpermeable channels in the plasma membrane of plant root cells. Biochim. Biophys. Acta 1564, 299-309.

White, P. J., Whiting, S. N., Baker, A. J. M., and Broadley, M. R. (2002b). Does zinc move apoplastically to the xylem in roots of Thlaspi caerulescens? New Phytol. 153, 201-207.

White, P. J., Bradshaw, J. E., Dale, M. F. B., Ramsay, G., Hammond, J. P., and Broadley, M. R. (2009). Relationships between yield and mineral concentrations in potato tubers. HortScience 44, 6-11.

White, P. J., and Broadley, M. R. (2005). Biofortifying crops with essential mineral elements. Trends Plant Sci. $10,586-593$.
White, P. J., and Broadley, M. R. (2009). Biofortification of crops with seven mineral elements often lacking in human diets - iron, zinc, copper, calcium, magnesium, selenium and iodine. New Phytol. 182, 49-84.

White, P. J., and Brown, P. H. (2010). Plant nutrition for sustainable development and global health. Ann. Bot. 105, 1073-1080.

Wirth, J., Poletti, S., Aeschlimann, B. Yakandawala, N., Drosse, B., Osorio, S., Tohge, T., Fernie, A. R., Gunther, D., Gruissem, W., and Sautter, C. (2009). Rice endosperm iron biofortification by targeted and synergistic action of nicotianamine synthase and ferritin. Plant Biotechnol. J. 7, 631-644.

World Health Organization (WHO). (2002). The World Health Report 2002. Geneva: World Health Organization.

Wu, J., Schat, H., Sun, R., Koornneef, M., Wang, X., and Aarts, M. G. M. (2007). Characterization of natural variation for zinc, iron and manganese accumulation and zinc exposure response in Brassica rapa L. Plant Soil 291, 167-180.

Wu, J., Yuan, Y.-X., Zhang, X.-W., Zhao, J., Song, X., Li, Y., Li, X., Sun, R., Koornneef, M., Aarts, M. G. M., and Wang, X. W. (2008). Mapping QTL for mineral accumulation and shoot dry biomass under different $\mathrm{Zn}$ nutritional conditions in Chinese cabbage (Brassica rapa L. ssp. pekinensis). Plant Soil 310, 25-40.

Wu, J., Zhao, F.-J., Ghandilyan, A. Logoteta, B., Guzman, M. O., Schat, H., Wang, X., and Aarts, M. G. M. (2009). Identification and functional analysis of two ZIP metal transporters of the hyperaccumulator
Thlaspi caerulescens. Plant Soil 325, 79-95.

Yang, X., Ye, Z. Q., Shi, C. H., Zhu, M. L., and Graham, R. D. (1998). Genotypic differences in concentrations of iron, manganese, copper, and zinc in polished rice grains. J. Plant Nutr. 21, 1453-1462.

Zhao, F. J., Lombi, E., Breedon, T., and McGrath, S. P. (2000). Zinc hyperaccumulation and cellular distribution in Arabidopsis halleri. Plant Cell Environ. 23, 507-514

Zhao, F. J., Su, Y. H., Dunham, S. J., Rakszegi, M., Bedo, Z., Mcgrath, S. P., and Shewry, P. R. (2009). Variation in mineral micronutrient concentrations in grain of wheat lines of diverse origin. J. Cereal Sci. 49, 290-295.

Conflict of Interest Statement: The authors declare that the research was conducted in the absence of any commercial or financial relationships that could be construed as a potential conflict of interest.

Received: 02 September 2011; accepted: 26 October 2011; published online: 17 November 2011.

Citation: White PJ and Broadley MR (2011) Physiological limits to zinc biofortification of edible crops. Front. Plant Sci. 2:80. doi: 10.3389/fpls.2011.00080

This article was submitted to Frontiers in Plant Nutrition, a specialty of Frontiers in Plant Science.

Copyright (c) 2011 White and Broadley. This is an open-access article subject to a non-exclusive license between the authors and Frontiers Media SA, which permits use, distribution and reproduction in other forums, provided the original authors and source are credited and other Frontiers conditions are complied with. 